\title{
PENGEMBANGAN FUNGSI KAWASAN RTH WADUK BATUJAI SEBAGAI RUANG PUBLIK DI KOTA PRAYA, KABUPATEN LOMBOK TENGAH, NTB
}

\section{THE DEVELOPMENT OF URBAN OPEN SPACE IN THE AREA OF BATUJAI DAM AS A PUBLIC SPACE AT PRAYA, CENTRAL LOMBOK, WEST NUSA TENGGARA}

\author{
Iqbal Prayadi Saputra
}

Dinas Pekerjaan Umum Kab. Lombok Tengah; iqbalps04@gmail.com

Info Artikel:

- Artikel Masuk: 31/07/2018

\begin{abstract}
ABSTRAK
Kawasan RTH waduk Batujai yang berperan sebagai ruang publik perkotaan Praya Kabupaten Lombok Tengah saat ini belum berfungsi dengan baik terhadap meningkatnya perkembangan kota. Meningkatnya pemanfaatan dan aktivitas di kawasan RTH sebagai tempat rekreasi, bermain, maupun olahraga tidak diikuti dengan peningkatan kualitas lingkungan serta penyediaan fasilitas penunjang yang memadai. Permasalahan lainnya adalah belum dikembangkannya kawasan RTH waduk Batujai ini secara optimal, sehingga diperlukan suatu kajian arahan pengembangan kawasan RTH waduk Batujai sebagai ruang publik. Penelitian ini bertujuan untuk mengkaji arahan pengembangan fungsi kawasan RTH di waduk Batujai sebagai ruang publik. Penelitian ini menggunakan pendekatan kuantitatif dengan metode penelitian survei melalui kuesioner terhadap 175 responden yang terdiri masyarakat setempat dan pengunjung RTH serta 100 wisatawan, dengan teknik simple random sampling. Teknik analisis menggunakan deskriptif kuantitatif dengan model gravitasi, distribusi frekuensi dan SWOT. Hasil penelitian menunjukkan bahwa pengembangan kawasan RTH Batujai berada pada posisi Stable growth strategy dengan arahan pengembangan; Dikembangkan sebagai rekreasi Taman Kota (urban park) dan hutan kota serta pengembangan rekreasi olahraga air; Peningkatan kuantitas dan kualitas fasilitas wisata; meningkatkan potensi daya tarik dan menambah atraksi wisata; meningkatkan kualitas aksesibilitas; penataan vegetasi; pelestarian perairan waduk, serta penataan area sempadan waduk dan sungai sekitar.

Kata Kunci : Pengembangan, RTH, Waduk, Ruang Publik, Ruang Publik, Rekreasi
\end{abstract}

\section{ABSTRACT}

The area of Batujai dam as urban open space in Praya City, Central Lombok, has not supported the city's increasing needs and activities. The issues are: urban open space is utilized as recreational and sport facilities yet it is not supported by the environmental qualities as well as adequate facilities in public space. The area of urban open space in Batujai dam has not been optimally developed. Based on those issues, there is a need to analyze and determine the development of open space in the area of Batujai dam as optimum public space. The method used in the research was quantitative research using questionnaire. The sample was conducted to 175 respondents which are the community of the area and the visitors and 100 respondents of travelers based on simple random sampling. Analysis used quantitative descriptive with gravitation model, distribution frequency, and SWOT analysis. The results shows that Batujai open space is potential to be developed as recreational area with the position of development on Stable growth strategy by: being developed as urban recreational using urban park theme, urban forest, and water sport recreastional; increasing the quantity and quality of recreation facilities; arrengement of vegetation; increasing and developing the attractiveness potential; increasing quality of acces; preservation of the reservoir area, and arrengement of the border of the reservoir and the river.

Key Words : Development, Urban Open Space, Dam/reservoir, Public Space, Recreation

Copyright $\odot 2016$ GJGP-UNDIP This open access article is distributed under a Creative Commons Attribution (CC-BY-NC-SA) 4.0 International license.

Cara men-sitasi (APA 6th Style):

Prayadi Saputra, Iqbal. (2018). Pengembangan Fungsi Kawasan Rth Waduk Batujai Sebagai Ruang Publik Di Kota Praya, Kabupaten Lombok Tengah, NTB, Vol 14 (2), $143-157$ 


\section{PENDAHULUAN}

Perkembangan perkotaan-perkotaan di Indonesia memberikan dampak pada tingginya tekanan terhadap pemanfaatan ruang kota untuk berbagai aktivitas juga berdampak negatif pada perlindungan alam (terjadinya penurunan fungsi ruang terbuka perkotaan), sehingga diperlukan penyeimbangan lingkungan dengan penyediaan ruang terbuka hijau (RTH) kota (Budihardjo \& Sujarto, 1999). Kawasan tepian/sempadan waduk adalah salah satu bentuk RTH kawasan perkotaan (Krier, 1979) yang mengelilingi waduk, merupakan bagian dari infrastruktur yang penting bagi kebutuhan warga.

Kota Praya, sebagai Ibu Kota Kabupaten Lombok Tengah memiliki kawasan waduk strategis yang berada tepat di jantung kawasan perkotaan yang juga berfungsi sebagai ruang publik kota. Kawasan RTH waduk Batujai ini memiliki panorama yang indah. Hal ini menjadi daya tarik tersendiri bagi masyarakat untuk rekreasi bersantai disore hari atau akhir pekan. Dalam beberapa tahun terakhir ini, pembangunan Kabupaten Lombok Tengah semakin pesat khususnya di kawasan perkotaan Praya. Sejak berdirinya Bandara Internasional Lombok (BIL) yang diikuti pembangunan infrastruktur pendukung, perubahan nyata terlihat pada pembangunan dan perubahan fisik kota menyebabkan terjadinya perluasan wilayah. Dampak hal tersebut dapat terlihat dari posisi dan peran kawasan waduk Batujai yang menjadi semakin strategis penghubung antara pusat kota dan Bandara. Sejalan dengan perkembangan di sekitar kawasan tersebut, mendorong tumbuhnya aktivitas yang begitu cepat. Sebagai ruang publik yang digunakan oleh komunitas sosial, kawasan RTH waduk Batujai harus mampu mengakomodir kebutuhan, keinginan, dan estetika yang juga beragam (Carr, 1992). Saat ini kondisi kawasan RTH waduk Batujai belum optimal dan kurang representatif sebagai ruang terbuka publik. Permasalahan yang terjadi antara lain:

1. Terjadi peningkatan pemanfaatan kawasan RTH sebagai tempat rekreasi, bermain, maupun olahraga yang tidak diikuti peningkatan kualitas lingkungan (tempat yang aman dan nyaman, bebas polusi, kebersihan waduk)

2. Belum dikembangkannya kawasan RTH waduk Batujai ini secara optimal sesuai dengan potensinya serta sesuai dengan minat dan permintaan masyarakat (demands) akan kebutuhan suatu sarana pendukung kegiatan.

Untuk itu, dalam rangka meningkatkan kawasan RTH di waduk Batujai, perlu dilakukan upaya pengembangan kawasan untuk peningkatan kualitas dan pemanfaatan ruang publik di Kota Praya yang ditujukan untuk melayani kegiatan rekreasi bagi kesejahteraan masyarakat (Carr,1992). Penelitian ini bertujuan untuk mengkaji arahan pengembangan fungsi kawasan RTH di waduk Batujai sebagai ruang publik agar optimal sesuai dengan potensi yang dimiliki serta dapat mengakomodir kebutuhan/keinginan masyarakat dan penggunanya. Penelitian ini berkontribusi bagi pengetahuan melalui pemanfaatan ruang terbuka hijau (RTH) sebagai ruang public bagi kesejahteraan masyarakat (Carr, 1992) melalui eksplorasi strategi penanganan dengan SWOT analisis yang tepat.

\section{DATA DAN METODE}

\subsection{Metode Penelitian}

Pendekatan yang digunakan dalam penelitian ini adalah penelitian kuantitatif dengan metode penelitian survei melalui kuesioner yang dilakukan terhadap 175 responden yang terdiri masyarakat sekitar kawasan dan pengunjung RTH serta 100 responden wisatawan (domestik dan mancanegara) menggunakan teknik simple random sampling. Teknik analisis yang digunakan adalah deskriptif kuantitatif dengan analisis gravitasi, distribusi frekuensi, dan SWOT.

\subsection{GAMBARAN UMUM KAWASAN RTH WADUK BATUJAI}

Kawasan RTH waduk Batujai berada tepat di tengah kawasan Perkotaan Praya yang merupakan Ibukota Kabupaten Lombok Tengah. Kawasan Waduk Batujai secara administratif sebagai pintu bendung (out flow) 
berada di Desa Batujai Kecamatan Praya Barat, sedangkan daerah genangan dan greenbelt nya melingkupi; kelurahan Panjisari, kelurahan Semayan, kelurahan Prapen, kelurahan Tiwugalih merupakan wilayah kecamatan Praya, kelurahan Sasake dan desa Lajut yang merupakan wilayah kecamatan Praya Tengah, dan Desa Batujai dan desa Penujak merupakan wilayah kecamatan Praya Barat (Lihat Gambar 1). Kawasan waduk ini memiliki posisi yang sangat strategis karena berada dekat pusat kota praya sebagai ibu kota Kabupaten Lombok Tengah dan bersebelahan dengan Bandara Internasional Lombok (BIL). Penggunaan lahan disekitar waduk Batujai yaitu terdiri atas area permukiman penduduk, area green belt, area persawahan, dan fasilitas kota lainnya. Waduk Batujai bukan hanya bendungan semata. Tempat tersebut juga dimanfaatkan sebagai destinasi wisata dan tempat pemancingan.

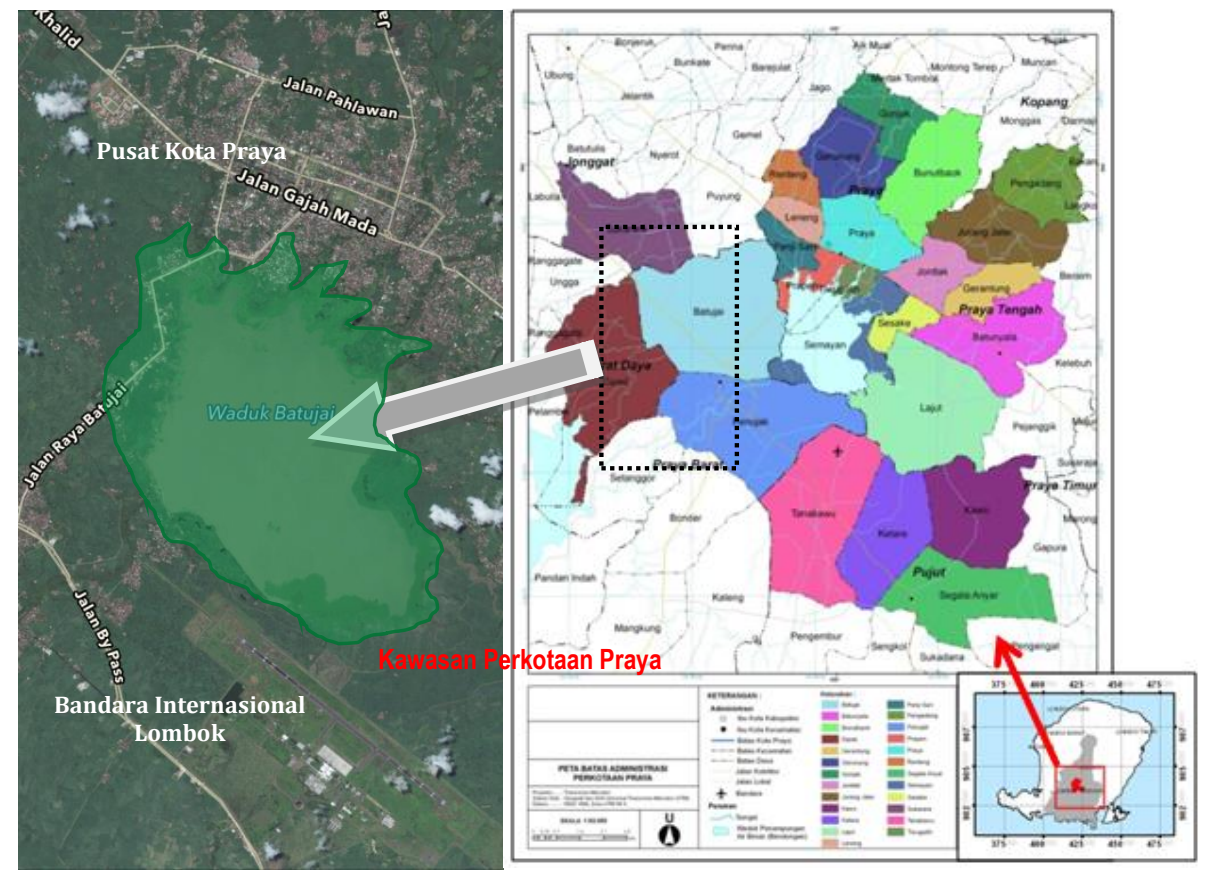

Gambar 1. Lokasi Kawasan Rth Waduk Batujai

(Sumber : Masterplan RTH Kawasan Perkotaan Praya 2012-2017)

\section{HASIL DAN PEMBAHASAN KAJIAN PENGEMBANGAN KAWASAN RTH SEBAGAI RUANG PUBLIK}

\subsection{Ruang Terbuka Hijau (RTH)}

Menurut Trancik (1986), ruang terbuka hijau adalah ruang yang didominasi oleh lingkungan alami di luar maupun didalam kota, dalam bentuk taman, halaman, areal rekreasi kota dan jalur hijau. Sementara menurut Lynch (1991), ruang terbuka hijau adalah lahan yang digunakan untuk berbagai kegiatan termasuk di dalamnya olahraga dan bermain, pada suatu area yang luas dengan sifat kepemilikan publik atau semi publik, pada lahan yang tidak terbangun dan tidak memiliki bangunan di atasnya, pada lahan terbuka pemandangannya atau pada tempat-tempat yang berada di luar bangunan. Kriteria fungsi utama RTH berdasarkan tipologi untuk kawasan perkotaan adalah sebagai berikut (Hakim, 1991):

- Fungsi sosial \& budaya, yaitu sebagai ekspresi budaya lokal, media interaksi warga, dan tempat rekreasi

- Fungsi estetika kawasan, yaitu untuk Meningkatkan kenyamanan kawasan, membentuk keindahan lanskap, dan menciptakan keserasian \& keseimbangan kawasan terbangun dan non terbangun

- Fungsi ekologis kawasan, yaitu sebagai paru-paru kota, pengatur iklim mikro, dan penyerap polusi air, udara, dan tanah. 
Menurut de Chiara dan Lee Kopellman (1975), ruang terbuka hijau perkotaan berfungsi untuk mempertahankan karakter kota dengan bentuk sebagai hutan kota dan taman kota. Taman kota mempunyai fungsi utama untuk estetika, interaksi sosial, dan rekreasi (Rapuano,1964). Hutan kota, mempunyai fungsi utama untuk peningkatan kualitas lingkungan dan juga rekreasi (Fakuara, 1987).

\subsection{RTH Sebagai Ruang Publik}

Ruang publik merupakan pengikat sosial untuk menciptakan interaksi antara kelompok masyarakat, sebagai tempat berkumpul sehari-hari dan berperan sebagai nodes dan landmark yang menjadi alat navigasi di dalam kota berwujud wadah yang dapat menampung aktivitas tertentu dari masyarakatnya, baik secara individu maupun secara kelompok, (Carr,1992; Lynch, 1960; Hakim, 1991).

RTH berfungsi sebagai tempat rekreasi dimana penduduk dapat melaksanakan kegiatan berbentuk rekreasi, dapat berupa rekreasi aktif seperti olahraga dan rekreasi pasif seperti taman. Terdapat lima kebutuhan dasar (aspek needs) yang dicari orang dalam ruang publik (Carr, 1992), yaitu:

a) Comfort. Kenyamanan di ruang publik dapat dilihat dari antara lain: ketersediaan tempat duduk, tempat makan/minum, pencahayaan/lampu penerangan, pohon peneduh atau shelter, dan pedestrian.

b) Relaxation. Suasana santai/rileks dapat dicapai dan diperoleh antara lain: tersedianya elemen alami (pepohonan, air, rerumputan) dan pembatas jalan jika badan dan fikiran dalam kondisi sehat dan senang (Carr, 1992).

c) Passive engagement. Penggunaan pasif yang dilakukan oleh pengguna ruang publik adalah mengamati lingkungan, antara lain: Menikmati panorama alam, dan mengamati aktivitas yang ada (Carr, 1992).

d) Active engagement. Terjadi dalam bentuk aktivitas secara langsung melibatkan pengguna. Aktivitasaktivitas tersebut antata lain: bermain/olahraga, jogging, bersepeda, memancing, berkumpul, senam, jalan santai.

e) Discovery. Pengalaman ruang yang beragam akan meningkatkan ketertarikan orang untuk terlibat di ruang publik seperti pertunjukkan live, pameran seni, teater jalanan, festival, parade, bazar, dan lainnya (Carr, 1992).

\subsection{Potensi Pengembangan Kawasan}

Pengembangan kawasan RTH perlu mempertimbangkan kondisi fisik eksisting dari lokasi kawasan sehingga bentuk pengembangan kawasan sesuai dengan karakteristik kawasan. Beberapa hal yang perlu diperhatikan terkait karakteristik kawasan antara lain yaitu (Chiara et all, 1975):

1. Kondisi lingkungan/geografis. Aspek geografi meliputi luas kawasan, luas area terpakai, dan juga batas administrasi serta batas alam.

2. Topografi. Kondisi topografi berfungsi untuk menentukan pengembangan penggunaan ruang untuk kegiatan yang sifatnya terbangun maupun non terbangun yang dilihat dari kontur kawasan RTH.

3. View, merupakan kejelasan antara orientasi manusia terhadap lingkungan yang dapat menjadi ciri khas atau sesuatu yang menarik pada kawasan tertentu. Hal ini diidentifikasi dengan cara mendapat gambaran terhadap view from site (view dari tapak kawasan) dan view to site (view ke arah kawasan) (Chiara et all, 1975).

4. Vegetasi. Fungsi dan manfaat RTH sangat tergantung kepada komposisi dan keanekaragaman jenis dari komunitas vegetasi yang menyusunnya dan kepada tujuan penggunanya (Grey dan Deneke, 1996).

Simonds (2006) merumuskan prosedur penting dalam menganalisis kawasan/tapak yaitu pengaruh regional (Regional Influences). Proses analisis tapak harus dimulai dengan lokasi-lokasi perencanaan pada peta regional dan penyelidikan tentang daerah di sekitarnya, serta aspek-aspek yang ada pada area perencanaan seperti topografi dan alam atau bangunan yang memiliki pengaruh pada penggunaan kawasan. 


\subsection{Pemanfaatan Waduk}

Pengelolaan waduk berdasarkan penataan ruang membagi perairan waduk atas kawasan sesuai peruntukannya dengan memperhatikan kondisi ligkungan fisik, biologis perairan dan sosial ekonomi sekitarnya (Siagian, 2014). Secara umum area waduk dapat dibedakan dalam beberapa kawasan yaitu kawasan bahaya, kawasan suaka/budidaya, Kawasan lindung dan kawasan bebas, serta kawasan perhubungan air (transportasi) dan rekreasi air (Dirjen Pengairan Departemen Pekerjaan Umum, 1983; Siagian, 2014).

\subsection{Aspek Supply and Demand Pengembangan Kawasan}

Tiga komponen utama sebagai aspek penawaran yang menentukan keberhasilan suatu tempat berkembang menjadi daerah tujuan wisata yaitu (Mill dan Morison, 1985; Gunn, 1998):

1. Daya Tarik/Atraksi, terdiri dari: daya tarik alam, daya tarik buatan/binaan manusia, daya tarik budaya, dan daya tarik sosial,

2. Amenitas / Fasilitas, merupakan segala macam fasilitas penunjang di kawasan pengembangan antara lain akomodasi, hotel/penginapan, tempat makan, area olahraga, serta fasilitas umum lainnya (Fandeli, 1995).

3. Aksesibilitas. Pencapaian dapat ditunjukkan dari kemudahan dan kenyamanan dalam mencapai tujuan serta ketersediaan transportasi (Lynch, 1960).

Sisi permintaan (demand) meliputi minat dan kemampuan penduduk untuk memanfaatkan ruang publik. Didalam aspek permintaan terdapat bagian segmentasi pasar yang menjadi langkah pengelompokkan manusia berdasarkan kesamaan kebutuhan dan keinginan sebagai bagian dari target pasar yang potensial (Gunn,1998).

\subsection{Pengembangan Fungsi Kawasan RTH Waduk Batujai Sebagai Ruang Publik}

a. Kawasan RTH Waduk Batujai dalam Skala Regional

Berdasarkan hasil Model Gravitasi/interaksi terhadap daerah-derah/kota lainnya di Pulau Lombok diperoleh bahwa kota Praya memiliki interaksi/ hubungan yang paling kuat dengan Kota Mataram. Hal ini menunjukkan bahwa frekuensi hubungan sosial dan ekonomi diantara kedua tempat tersebut lebih mudah terjadi yang berarti semakin potensial untuk berkembang karena jaraknya yang cukup dekat dan ditunjang akses jalan yang sangat baik (Tarigan, 2006), sehingga dapat dikatakan secara makro Kota Mataram adalah target pasar yang paling menguntungkan apabila Kota Praya mengembangkan kawasan RTH waduk Batujai sebagai destinasi rekreasi. Selain itu, posisi kawasan RTH waduk Batujai mempunyai tempat yang sangat potensial dalam kunjungan wisatawan lokal maupun mancanegara. Kawasan RTH waduk Batujai merupakan bagian dari perkotaan Praya yang selain dekat dengan ibu kota provinsi NTB yaitu kota Mataram, juga sangat dekat dengan Bandar Udara Internasional Lombok yang merupakan pintu masuk utama wisatawan.

b. Karakteristik Kawasan RTH Waduk Batujai

1. Fungsi RTH

Dari hasil penelitian, masyarakat merasakan keberadaan RTH waduk Batujai bagi perkotaan lebih dominan berfungsi ekologis terutama sebagai paru-paru kota dan fungsi sosial khususnya untuk rekreasi. Hal tersebut menunjukkan bahwa masyarakat menganggap keberadaan RTH waduk Batujai memberi manfaat sebagai penghasil udara bersih dan segar sehingga menjadikan suasana lingkungan menjadi sejuk dan nyaman bagi aktivitas masyarakat kota (Fakuara, 1987; Rapuano, 1964). Selain itu, suasana alami dan nyaman melalui keberadaan vegetasinya dapat meningkatkan daya tarik orang untuk untuk berkunjung (Branch, 1995) sehingga selama ini RTH waduk Batujai dimanfaatkan oleh masyarakat sebagai sarana rekreasi seperti bersantai, bermain, olahraga, ataupun bersosialisasi antar warga sekitarnya.

2. Kondisi Fisik Lingkungan dan Topografi 
Topografi relatif datar (0-2\%) dan memiliki area teroptimal berpotensi untuk dikembangkan pemanfaatannya berdasarkan luasan masing-masing area yaitu RTH kelurahan Tiwugalih, Panjisari dan Prapen, Desa Batujai, Desa Penujak, Kelurahan Semayan dan Sasake; serta Desa Lajut .

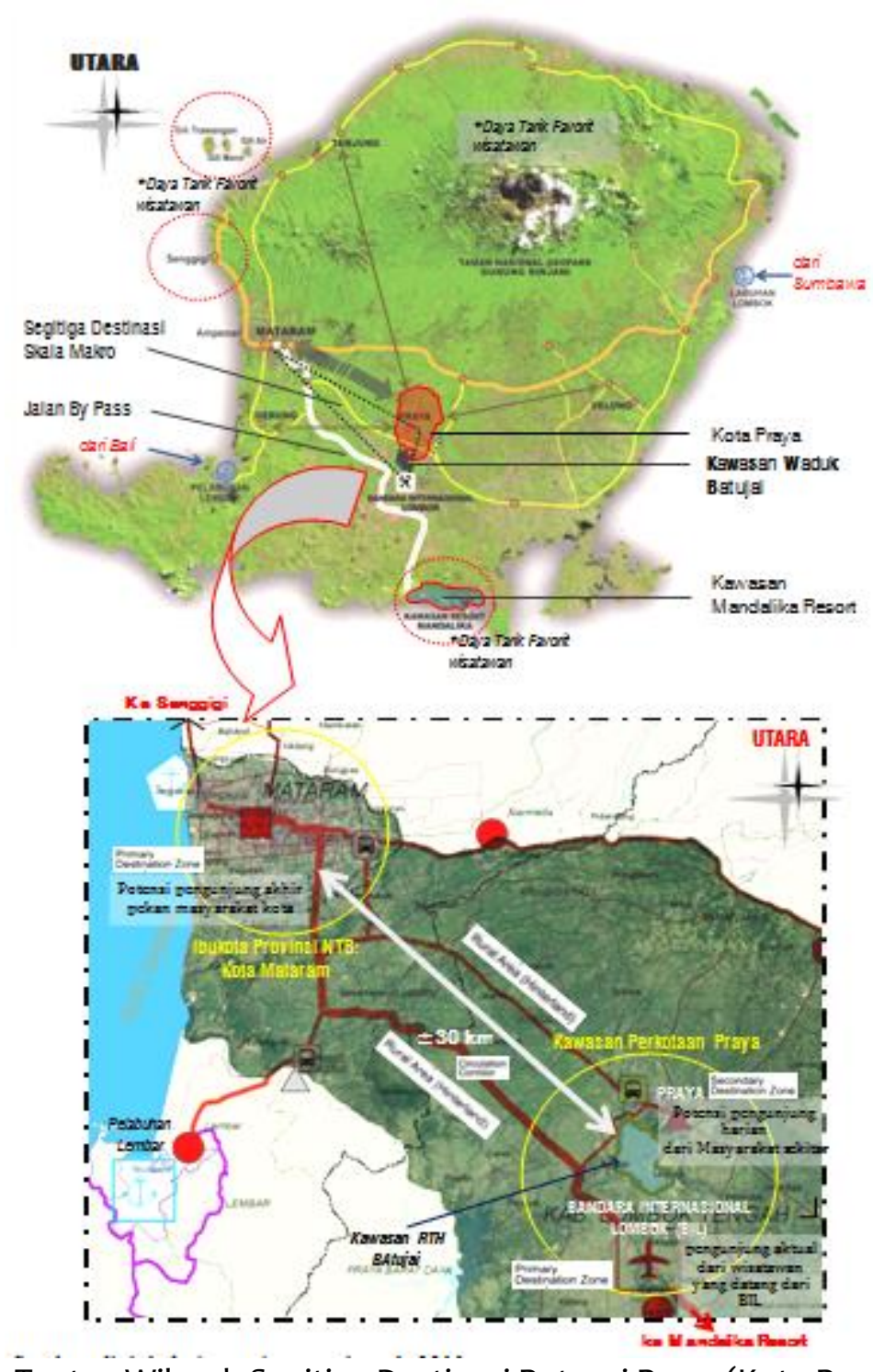

Gambar 2. Tautan Wilayah Segitiga Destinasi Potensi Pasar (Kota Praya - Bil - Mataram)

3. View

Dari hasil penelitian diperoleh sebagian besar masyarakat menyatakan view kawasan RTH waduk Batujai berupa pemandangan/panorama alam. Hal ini menunjukkan bahwa masyarakat lebih mengenal dan menikmati view di kawasan waduk Batujai karena memiliki panorama alam yang indah yaitu berupa lansekap ruang terbuka dengan orientasi hamparan air waduk yang luas disertai hamparan persawahan dan dikelilingi pepohonan hijau yang rindang berlatarkan pegunungan, sehingga merupakan tempat yang nyaman dan menyenangkan secara visual di lingkungan kawasan perkotaan (Shirvani, 1985).

4. Vegetasi

Mayoritas responden menyatakan kawasan RTH Batujai tersedia vegetasi peneduh dan memiliki jenis vegetasi yang beragam yang menunjukkan bahwa kawasan RTH waduk Batujai cukup rindang dengan tersedia banyaknya vegetasi peneduh sehingga mengindikasikan RTH waduk Batujai nyaman 
untuk menunjang kebutuhan beraktivitas (bersantai, berjalan, berolahraga, ataupun rekreasi), karena sesuai yang dikemukakan Carr (1992) bahwa kenyamanan beraktivitas di ruang publik diantaranya didukung oleh ketersediaan pohon peneduh. Selain itu, persepsi responden terhadap pola sebaran vegetasi, sebagian besar responden menyatakan pepohonan di kawasan RTH Batujai tersebar merata. hal ini menunjukkan bahwa sebaran pepohonan di kawasan RTH waduk Batujai saat ini dianggap cukup dapat bermanfaat untuk memperbaiki kualitas lingkungan, karena semakin banyak tersebar tanaman maka semakin meningkatkan kemampuan RTH dalam menanggulangi permasalahan lingkungan (Hakim, 2004; Fakuara, 1987). Disisi lain, sebagian besar kawasan penanaman vegetasinya tidak terencana sehingga tidak berpola dan cenderung acak.

5. Sosial Ekonomi Budaya Masyarakat Setempat

Ditinjau dari mata pencaharian, usia produktif, tingkat pendidikan dan ekonomi, serta kebudayaan masyarakat setempat sangat mendukung untuk pengembangan kawasan RTH Batujai dalam hal peran aktif, pemberdayaan, kesempatan usaha dan peluang kerja bagi masyarakat sekitar, serta kebutuhan akan rekreasi yang memberi rasa nyaman.

6. Daya Tarik

Kawasan ini dipilih sebagai tempat bersantai dan rekreasi karena memiliki panorama alam yang indah berupa hamparan pepohonan hijau dan hamparan air waduk yang luas yang membuat suasana kawasan menjadi asri, sejuk, dan segar serta menjadi pemandangan lepas yang indah sehingga menarik mereka untuk melakukan berbagai kegiatan relaksasi dan olahraga ringan (Carr, 1992). Selain itu terdapat taman rekreasi (Tonjeng Beru Smart Garden) dan waduk Batujai yang menjadi tarikan masyarakat sebagai tempat bersosialisasi dengan fasilitas pendukung ruang publik seperti tempat duduk, gazebo, dan pedestrian serta PKL (pedagang kaki lima). Atrakasi-atraksi tersebut juga menciptakan satu kesatuan panorama alam yang indah yang dapat dinikmati masyarakat (Mill \& Morison, 1985). Berdasarkan pengamatan, banyak pengunjung datang ke RTH waduk Batujai diwaktu sore hari sampai menjelang senja hanya untuk menikmati pesona langit sunset dengan latar panorama hamparan air waduk, pepohonan dan persawahan serta pegunungan (view gunung Sasak dan Rinjani). Adapun potensi sosial dan budaya yang dapat dikembangkan di RTH Batujai seperti tata cara hidup masyarakat setempat, kesenian tradisional, musik, dan festival budaya (seperti upacara adat, tradisi perang topat, olahraga peresean, rangkaian acara pernikahan/nyongkolan dan khitanan, tarian daerah, seni pahat, dan wayang).

7. Aksesibilitas

Dari segi pencapaian, masyarakat beranggapan kawasan RTH sudah sangat aksesibel karena lokasinya yang strategis yaitu dekat dengan pusat Kota Praya dan dapat dijangkau dari segala arah. Di sisi lain, moda transportasi yang digunakan pengguna lebih banyak kendaraan pribadi (mobi/motor), sehingga berdampak pada penyediaan lahan parkir dan dibutuhkan pengaturan dan penataan area parkir yang tepat karena kondisi saat ini sangat kurang memadai baik dari sisi kenyamanan maupun keamanan.

8. Fasilitas

Berdasarkan hasil penelitian diperoleh ketersediaan dan kondisi fasilitas di sekitar kawasan RTH waduk Batujai, yaitu:

- Akomodasi yang ada sudah memadai dan mudah ditemukan yaitu hotel dan wisma/guest house. Namun perlu adanya jenis penginapan yang lebih beragam/variatif dan lokasi sebaran yang merata.

- Tempat makan di sekitar kawasan RTH Batujai terbilang cukup banyak, terutama didominasi oleh warung makan, kafe, dan PKL makanan.

- Transportasi umum yang tersedia hanya andong/becak (cidomo), taksi, dan ojek. Angkutan massal seperti angkot dan bus sangat minim/jarang.

- Terdapat tempat pemancingan, jalur sepeda, dan lapangan terbuka sebagai sarana olahraga \& bermain yang tersedia namun tidak tertata dan kurang memadai. Sedangkan jogging track, playground tidak tersedia. 
- Fasilitas umum publik yang masih kurang memadai dan perlu ditingkatkan yaitu WC umum dan pedestrian.

c. Pemanfaatan Kawasan RTH sebagai Ruang Publik

Pemanfaatan Ruang Terbuka Hijau (RTH) sebagai ruang public sangat penting dan berkontribusi bagi integrase social (Hong, 2017)

1. Zonasi Pemanfaatan Kawasan Waduk

Penggunaan lahan di sekitar kawasan RTH waduk Batujai yang paling dominan adalah area persawahan dan permukiman. Kawasan RTH waduk Batujai selama ini dimanfaatkan masyarakat perkotaan sebagai sarana rekreasi bersantai, olahraga, dan hiburan. Sedangkan penduduk lokal sekitar kawasan memanfaatkan keberadaan RTH untuk lahan pertanian. Zona pemanfaatan kawasan RTH waduk Batujai dibagi 4 yaitu kawasan bahaya (area sekitar pintu air bendung), kawasan suaka (merupakan sempadan waduk dan sungai berjarak 50-100 m dari permukaan air tertinggi), Kawasan lindung (kawasan sabuk hijau atau green belt dengan pemanfaatan terbatas) dan kawasan bebas (berada di sebagian area terluas yaitu kelurahan Tiwugalih, Sasake dan Desa Lajut).

2. Aktivitas

- Kenyaman beraktivitas di RTH Batujai diperoleh dengan tersedianya tempat naungan (gazebo dan pohon peneduh) dan tempat duduk/bangku taman yang memadai

- Suasana relaksasi/rileks (kenyamanan psikis dan rasa tenang) di RTH Batujai didapat dengan keberadaan pepohonan dan hamparan air waduk.

- Aktivitas yang dilakukan sangat beragam, didominasi oleh kegiatan aktif antara lain memancing, bersepeda, jalan santai, bermain, jogging, senam, dan lain-lain sebanyak $72 \%$. Sedangkan kegiatan pasif yaitu menikmati panorama alam dan mengamati aktivitas yang ada sebesar $28 \%$. Artinya, dapat dikatakan bahwa jenis RTH waduk Batujai adalah RTH aktif.

- Festival/parade budaya dan pertunjukan musik adalah event yang paling sering diadakan di kawasan RTH waduk Batujai sebagai keragaman kegiatan (aktivitas pendukung sebagai tontonan).

\subsection{Preferensi Masyarakat dan Pengunjung Terkait Pengembangan RTH}

1. Fungsi RTH yang diminati sebagian besar masyarakat adalah sebagai fungsi ekologis khususnya sebagai paru-paru kota (32\%) dan Fungsi sosial (36\%) khususnya untuk rekreasi (38\%). Hal ini menunjukkan bahwa masyarakat menginginkan kawasan RTH Batujai harus tetap mengedepankan terjaganya kualitas lingkungan untuk meningkatkan ketersediaan udara bersih perkotaan yang nyaman.

2. Preferensi jenis RTH yang lebih diminati masyarakat yaitu taman kota (67\%) dibanding dengan hutan kota (33\%). Artinya, bahwa kawasan RTH waduk Batujai lebih diminati masyarakat apabila dikembangkan sebagai taman kota dikarenakan oleh karakter kawasan RTH waduk Batujai yang memiliki tingkat aksesibilitas dan aktivitas yang tinggi .

3. Daya tarik yang paling diminati sebagian besar responden adalah daya tarik alam (60\%) terutama mengandalkan hamparan pepohonan (37\%) dan perairan waduk (14\%). Selain itu daya tarik buatan (28\%) mengandalkan taman rekreasi (25\%), dan tarik budaya (12\%) berupa festival musik dan kebudayaan (6\%). Artinya masyarakat/pengunjung cenderung menyukai atraksi berbasis keindahan alam yang sesuai dengan karakter RTH Batujai.

4.Untuk mencapai ruang publik dengan tujuan rekreasi, masyarakat lebih memilih tempat rekreasi yang dekat dengan pusat kota (39\%) dan tempat yang mudah dijangkau dari segala arah (25\%). Di sisi lain, moda transportasi menunjukkan mayoritas responden mempunyai 
keinginan bersepeda (29\%) dan berjalan kaki (23\%) dibandingkan menggunakan mobil/motor (20\%).

5. Preferensi masyarakat terhadap fasilitas di kawasan RTH waduk Batujai ditemukan bahwa keinginan/harapan pengunjung yang datang diwaktu mendatang perlu penambahan fasilitas antara lain seperti penginapan yang murah (wisma), villa, kafe, spot-spot lokasi pemancingan yang lebih menarik dan tertata, tempat parkir di dalam kawasan, WC umum yang memadai, jogging track dan jalur pedestrian.

6.Sarana rekreasi yang diminati masyarakat cukup beragam. Jenis rekreasi yang cukup banyak peminatnya antara lain taman bunga $23 \%$, sepeda air/wahana perahu $14 \%$, kolam renang $12 \%$, dan panggung/amphiteater masing-masing $11 \%$. Sedangkan rekreasi yang diminati wisatawan sebagian besar adalah banana boat (18\%), ski air (15\%), parasailing (14\%), dan waterball/bola air (10\%). Hal ini berarti untuk menarik jangkauan yang lebih luas, kebutuhan dan pelayanan serta fasilitas yang diperlukan adalah yang berkaitan dengan aktivitas-aktivitas tersebut.

Tabel 1. Skoring Analisis Faktor (Sumber: Hasil Analisis, 2016)

\begin{tabular}{|c|c|c|c|c|}
\hline No. & STRENGTH & Вовот & RATING & SKOR \\
\hline 1. & $\begin{array}{l}\text { Pemandangan alam kawasan RTH Batujai yang } \\
\text { indah berupa hamparan pepohonan, persawahan, } \\
\text { hamparan air yang luas berlatar pegunumgan }\end{array}$ & 0,22 & 4 & 0,86 \\
\hline 2. & $\begin{array}{l}\text { Tersedia fasilitas tempat makan, sarana olahraga, } \\
\text { bermain, serta taman rekreasi }\end{array}$ & 0,08 & 3 & 0,24 \\
\hline 3. & $\begin{array}{l}\text { Peraiaran waduk yang luas dapat dimanfaatkan } \\
\text { sebagai wisata pemancingan \& budidaya perikan } \\
\text { darat serta olahraga/wisata air }\end{array}$ & 0,08 & 3 & 0,24 \\
\hline 4. & $\begin{array}{l}\text { Vegetasi yang ada cukup beragam, tersebar merata, } \\
\text { dan menciptakan keteduhan sehingga memberi } \\
\text { rasa kenyamanan bagi pengguna. }\end{array}$ & 0,19 & 3 & 0,57 \\
\hline \multirow[t]{2}{*}{5.} & $\begin{array}{l}\text { Sudah menjadi ruang terbuka publik kota yang } \\
\text { dimanfaatkan untuk berbagai aktivitas rekreasi dan } \\
\text { pegelaran event festival budaya }\end{array}$ & 0,08 & 3 & 0,24 \\
\hline & Total Kekuatan & 0,65 & & 2,16 \\
\hline No. & WEAKNESS & ВОВОт & RATING & SKOR \\
\hline 1. & $\begin{array}{l}\text { Beberapa fasilitas pendukung ruang publik tidak } \\
\text { memadai baik segi kualitas maupun kuantitasnya } \\
\text { seperti WC umum, pedestrian, tempat bermain } \\
\text { anak, jogging track dan area parkir }\end{array}$ & 0,16 & 1 & 0,16 \\
\hline 2. & $\begin{array}{l}\text { Kurangnya jenis/sarana rekreasi yang sesuai minat } \\
\text { masyarakat agar meningkatkan daya tarik untuk } \\
\text { berkunjung }\end{array}$ & 0,03 & 2 & 0,05 \\
\hline 3. & $\begin{array}{l}\text { Vegetasi RTH kurang tertata sehingga kurang } \\
\text { memberi kesan keindahan/estetika }\end{array}$ & 0,03 & 3 & 0,08 \\
\hline \multirow[t]{2}{*}{4.} & $\begin{array}{l}\text { Meningkatnya tekanan pemanfaatan lahan (hunian } \\
\text { dan pertanian) di sekitar RTH waduk dan } \\
\text { sempadan sungai sehingga mempersempit ruang } \\
\text { terbuka dan waduk tercemar sampah dan limbah } \\
\text { rumah tangga }\end{array}$ & 0,14 & 3 & 0,41 \\
\hline & Total Kelemahan & 0,35 & & 0,70 \\
\hline \multicolumn{4}{|c|}{ Selisih Total Kekuatan - Total Kelemahan $=\mathrm{S}-\mathrm{W}=\mathrm{x}$} & 1,46 \\
\hline
\end{tabular}


Tabel 2. Skoring Analisis Faktor Eksternal (Sumber: Hasil Analisis, 2016)

\begin{tabular}{|c|c|c|c|c|}
\hline No. & OPPORTUNTIES & ВОВОТ & RATING & SKOR \\
\hline 1. & $\begin{array}{l}\text { Perkembangan fisik kota mendorong tumbuhnya } \\
\text { aktivitas serta sarana danprasarana pendukmg seperti } \\
\text { kebutuhan tempat rekreasi }\end{array}$ & 0,11 & 3 & 0,32 \\
\hline 2. & $\begin{array}{l}\text { Aksesibilitas yang tinggi karena lokas yang strategis } \\
\text { (dekat dengan pusat kota Praya, Kota Mataram, } \\
\text { Bandara Internasional Lombok, dan Kawasan } \\
\text { Mandalika Resort), infrastrultur jalan dantransportasi } \\
\text { yang memadai, dilalui jalur utama; serta bisa } \\
\text { dijangkau dari segala arah }\end{array}$ & 0,25 & 4 & 1,00 \\
\hline 3. & $\begin{array}{l}\text { Keterkatan/kedekatan dengan destinasi selitar } \\
\text { terutama Kota Mataram, dan BIL sangat } \\
\text { menguntungkandari sisi demands untukmendapafkan } \\
\text { target pengunjung/segmentasi pasar secara makro } \\
\text { (wisatawan dan masyarakat lokal) }\end{array}$ & 0,11 & 4 & 0,43 \\
\hline 4. & $\begin{array}{l}\text { Tersedia fasilitas penginapan (hotel dan wisma/guest } \\
\text { house) yang dekat dengan kawasan RTH waduk } \\
\text { Batujai }\end{array}$ & 0,04 & 3 & 0,11 \\
\hline 5. & $\begin{array}{l}\text { Minat masyarakat yang tinggi terhadap daya tarik } \\
\text { alam untuk melakukan berbagai aktivitas berolahraga, } \\
\text { bermain serta rekreasi, serta minat terhadap adanya } \\
\text { festival budaya \& kesenian di sekitar kawasan }\end{array}$ & 0,14 & 3 & 0,43 \\
\hline 6. & $\begin{array}{l}\text { Kebijakan Pemerintah mendorong pengembangan } \\
\text { dalam mengoptimalkan keberadaan Waduk Batujai } \\
\text { untuk kegiatan RTH dan potensi wisata }\end{array}$ & 0,18 & 2 & 0,36 \\
\hline & $\begin{array}{c}\text { Total Peluang } \\
\end{array}$ & 0,82 & & 2,64 \\
\hline No. & THREATH & ВОВОТ & RATING & SKOR \\
\hline 1. & $\begin{array}{l}\text { Ancaman kerusakan lingkungan jika tidak ada } \\
\text { pengendalian terhadap meningkatnya berbagai } \\
\text { aktivitas untuk rekreasi dan rentan terjadinya alih } \\
\text { fungsi lahan } R T H \text { akibat perkembangankawasan dan } \\
\text { meningkatnya laju pertumbuhan penduduk yang } \\
\text { menuntut pemenuhan kebutuhan hunian }\end{array}$ & 0,14 & 2 & 0,29 \\
\hline 2. & $\begin{array}{l}\text { Terdapat ruang publik Alun-Alun Tastura sebagai } \\
\text { kompetitor danmasih kalah populer dengan wisata } \\
\text { alam pantai yang menjadi andalan kepariwisataan } \\
\text { khususnya di Lombok Tengah }\end{array}$ & 0,04 & 3 & 0,11 \\
\hline & $\begin{array}{c}\text { Total Ancaman } \\
\end{array}$ & 0,18 & & 0,39 \\
\hline \multicolumn{4}{|c|}{ Selisih Total Peluang - Total Ancaman $=\mathrm{O}-\mathrm{T}=\mathrm{y}$} & 2,25 \\
\hline
\end{tabular}

Adapun tabel IFAS dan EFAS terkait penentuan faktor internal dan eksternal strategi pengembangan kawasan RTH waduk Batujai dapat dilihat pada tabel dibawah ini. 


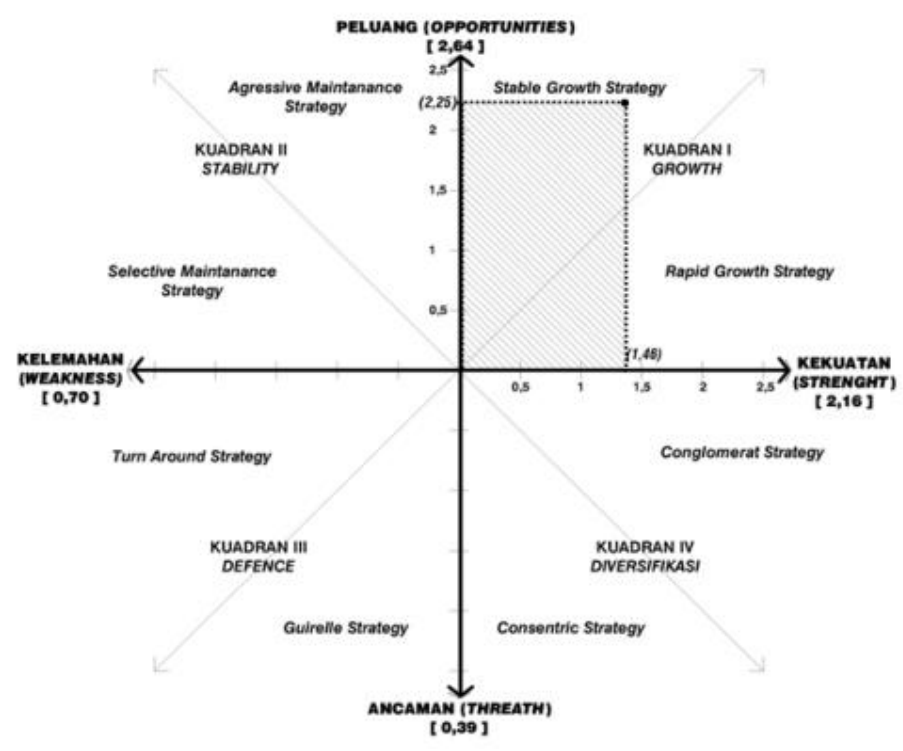

Gambar 3. Kuadran IFAS - EFAS

Letak kuadran strategi pengembangan berdasarkan analisis Kekuatan-Kelemahan (IFAS) diperoleh skor $+1,46$ dan nilai skor Peluang-Ancaman skor EFAS adalah $+2,25$ dari analisis SWOT, maka pemetaan strategi pengembangan Kawasan RTH waduk Batujai terletak pada kuadran satu, yaitu strategi S-O atau strategi pertumbuhan yang merupakan strategi untuk meningkatkan laju pertumbuhan melalui pengembangan secara bertahap dan target disesuaikan dengan kondisi eksisting, peningkatan kualitas yang menjadi faktor kekuatan untuk memaksimalkan pemanfaatan peluang.

\section{Analisis SWOT Potensi dan Permasalahan Pengembangan Kawasan RTH}

Tabel 3. Matriks SWOT (Sumber: Hasil Olah Data, 2016)

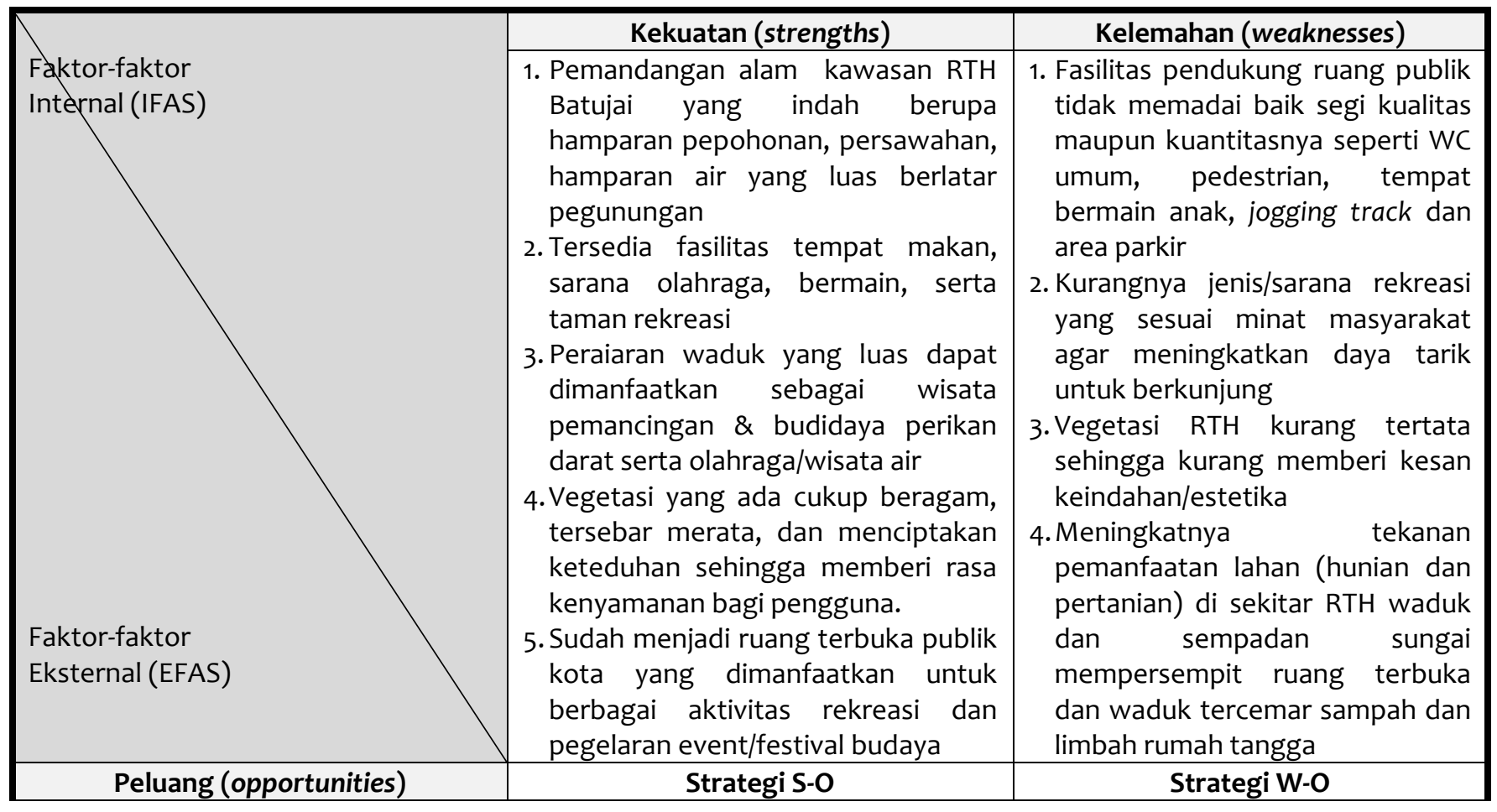




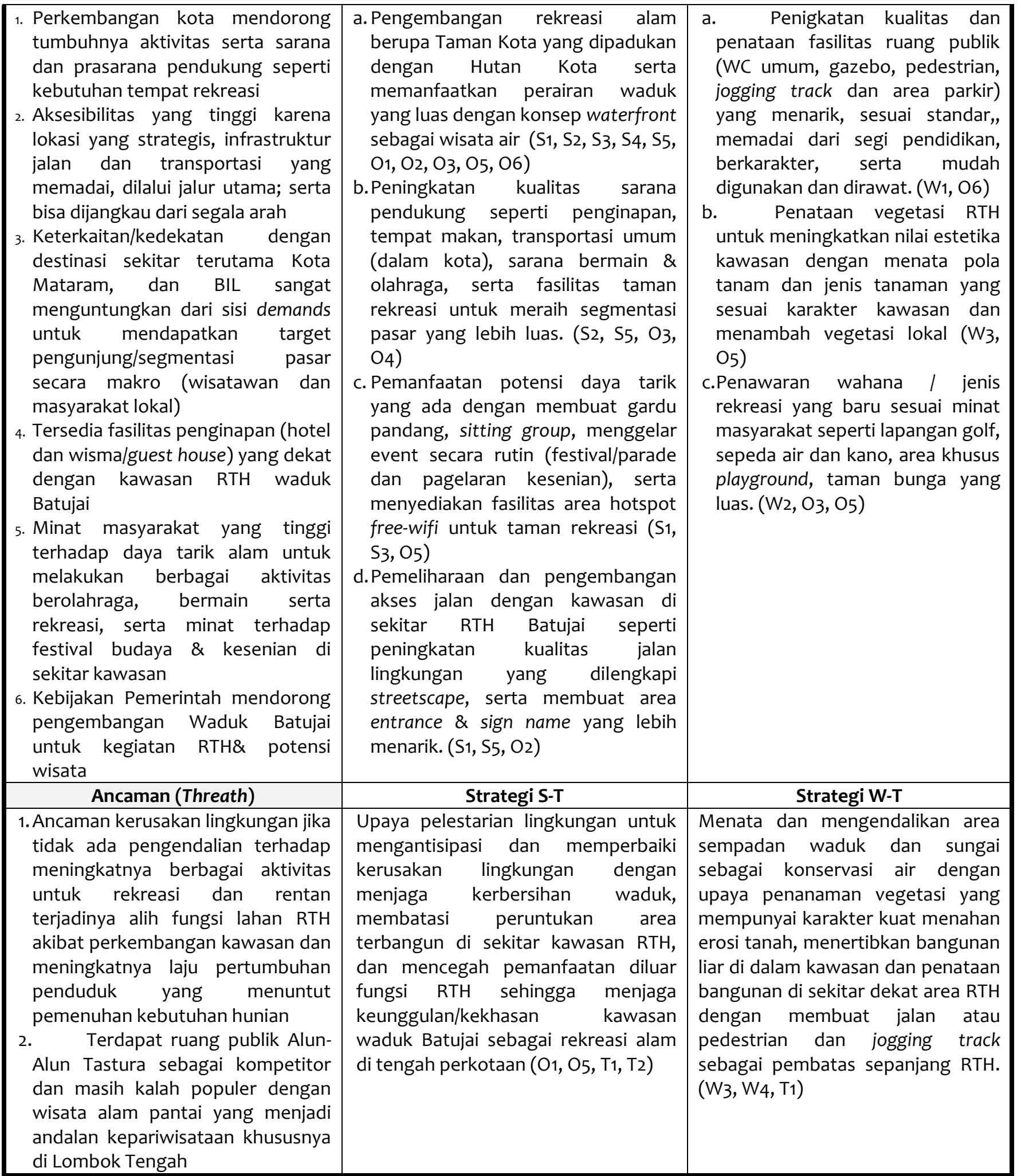

Berdasarkan hasil analisis SWOT diatas, maka strategi tersebut dapat diuraikan sebagai Arahan pengembangan kawasan RTH waduk Batujai yaitu:

- Dikembangkan sebagai Taman Kota (Urban Park) yang dipadukan dengan Hutan Kota agar dapat memaksimalkan fungsi ekologis, sosial, dan estetikanya. Konsep pengembangan waterfront/orientasi ke arah waduk dengan menyediakan sirkulasi di sepanjang tepian waduk lengkap dengan fasilitas 
bangku dan shelter. Adapun pemanfaatan untuk aktivitas rekreasi ataupun pemanfaatan lainnya diatur dalam zonasi-zonasi pengembangan.

- Peningkatan kuantitas dan kualitas fasilitas seperti penginapan (wisma/losmen dan villa); tempat makan (menyediakan cafe, warung makan, dan sentra kuliner yang unik dengan menu khas Lombok, serta penyediaan area khusus bagi PKL); transportasi umum \& pedestrian; sarana bermain \& olahraga (area pemancingan, jogging track, jalur sepeda, lapangan terbuka, dan tempat bermain anak/playground yang lebih layak.); serta fasilitas umum ruang publik (penyediaan WC umum portabel, gazebo, dan tempat duduk).

- Meningkatkan pemanfaatan potensi daya tarik yang ada dengan membuat gardu pandang, siiting group, mengadakan event secara rutin (festival/parade dan pagelaran kesenian), serta menyediakan fasilitas area hotspot free-wifi.

- Pemeliharaan dan pengembangan akses jalan dengan kawasan lainnya di sekitar RTH Batujai melalui peningkatan kualitas jalan lingkungan di sekitar kawasan yang dilengkapi streetscape serta membuat gerbang masuk (entrance \& sign name) RTH yang lebih menarik dan berkarakter khas Lombok.

- Peningkatan kualitas dan penataan vegetasi. Diperlukan pengembangan tata hijau yaitu penambahan vegetasi peneduh pada lokasi yang belum ditumbuhi oleh vegetasi. Komposisi dan jenis vegetasi pada ruang terbuka hijau perlu disesuaikan dengan kondisi lingkungan setempat dan karakter area yang ingin dicapai, memanfaatkan tanaman lokal, serta memilih vegetasi dengan komposisi yang menarik secara visual (meningkatkan estetika kawasan perkotaan).

- Mengembangkan wahana/jenis rekreasi baru untuk meningkatkan daya tarik kawasan dengan prioritas seperti taman bunga, area playground, dan mini golf, banana boat, ski air, parasailing, dan bola air.

- Upaya pelestarian lingkungan untuk mengantisipasi dan memperbaiki kerusakan lingkungan dengan menjaga kerbersihan waduk, membatasi peruntukan area terbangun di sekitar kawasan RTH, dan mencegah pemanfaatan diluar fungsi RTH

- Menata dan mengendalikan area sempadan waduk dan sungai sebagai konservasi air dengan upaya penanaman vegetasi yang mempunyai karakter kuat menahan erosi tanah, menertibkan bangunan liar di dalam kawasan dan penataan bangunan di dekat area RTH dengan membuat jalan atau pedestrian dan jogging track sebagai pembatas sepanjang RTH

Selain penjabaran diatas, hal yang cukup penting dalam pengembangan Ruang Terbuka Hijau (RTH) adalah aksesibilitas RTH bagi penghuni kotanya itu sendiri (Zlender, 2017) dan hal ini terakomodasi oleh keberadaan RTH Waduk Batujai.

\section{KESIMPULAN}

1. Kawasan Ruang Terbuka Hijau waduk Batujai memiliki potensi-potensi yang mendukung pengembangan sebagai kawasan rekreasi kota, yaitu: 1) Aksesibilitas yang tinggi karena berada pada lokasi yang strategis yaitu keterkaitan/kedekatan secara geografis dengan kawasan/destinasi penting yaitu Kota Praya, Bandara Internasional Lombok, Kota Mataram, dan Mandalika Resort, sehingga memudahkan untuk mendapatkan target/segmentasi pasar; 2) Keberadaan RTH waduk Batujai menjadikan suasana lingkungan menjadi sejuk dan nyaman bagi aktivitas masyarakat kota seperti bersantai, bermain, olahraga, ataupun bersosialisasi; 3) Vegetasi yang ada cukup beragam, tersebar merata, dan menciptakan keteduhan sehingga memberi rasa nyaman bagi penggunanya; 4) Memiliki daya tarik antara lain; pemandangan alam/lansekap (hamparan pepohonan dan hamparan air waduk), taman rekreasi (Tonjeng Beru) dan pintu air waduk, tata cara hidup masyarakat, serta festival budaya dan kesenian; 5) Kemudahan pencapaian ke RTH waduk Batujai sangat baik (aksesibilitas tinggi); 6) Fasilitas/amenitas (akomodasi, tempat makan, transportasi umum, ruang bermain dan olahraga, parkir, serta fasilitas umum ruang publik) yang ada di kawasan RTH waduk Batujai sudah cukup tersedia/memadai; 7) Sudah menjadi ruang terbuka publik kota yang dimanfaatkan untuk berbagai 
aktivitas olahraga, bermain, dan rekreasi, serta pegelaran event/festival budaya. Aktivitas yang ada antara lain didominasi kegiatan memancing, bersepeda, jalan santai, dan menikmati panorama alam.

2. Berdasarkan strategi hasil analisis SWOT, maka Arahan pengembangan kawasan RTH waduk Batujai adalah: 1) Dikembangkan sebagai Taman Kota (Urban Park) dan Hutan Kota dengan konsep waterfront/orientasi serta pemanfaatan perairan waduk untuk rekreasi olahraga air; 2) Peningkatan kuantitas dan kualitas fasilitas seperti penginapan (wisma/losmen dan villa); tempat makan (menyediakan cafe, warung makan, dan sentra kuliner yang unik dengan menu khas Lombok, serta penyediaan area khusus bagi PKL); transportasi umum \& pedestrian; sarana bermain \& olahraga (area pemancingan, jogging track, jalur sepeda, lapangan terbuka, dan tempat bermain anak/playground yang lebih layak.); serta fasilitas umum ruang publik (penyediaan WC umum portabel, gazebo, dan tempat duduk); 3) Meningkatkan pemanfaatan potensi daya tarik yang ada dengan membuat gardu pandang, siiting group, mengadakan event secara rutin (festival/parade dan pagelaran kesenian), serta menyediakan fasilitas area hotspot free-wifi; 4) Pemeliharaan dan pengembangan akses jalan di sekitar RTH Batujai melalui peningkatan kualitas jalan lingkungan yang dilengkapi streetscape serta membuat gerbang masuk (entrance \& sign name) RTH yang lebih menarik dan berkarakter khas Lombok; 5) Peningkatan kualitas dan penataan vegetasi yang disesuaikan dengan kondisi lingkungan setempat dan karakter area yang ingin dicapai, memanfaatkan tanaman lokal, serta memilih vegetasi dengan komposisi yang menarik; 6) Mengembangkan wahana/jenis rekreasi baru seperti taman bunga, area playground, dan mini golf. Rekreasi olahraga air seperti banana boat, ski air, parasailing, dan bola air; 7) Menjaga kerbersihan perairan waduk, membatasi peruntukan area terbangun di sekitar kawasan RTH, dan mencegah pemanfaatan diluar fungsi RTH; 8) Menata dan mengendalikan area sempadan waduk dan sungai sebagai konservasi air dengan upaya penanaman vegetasi yang mempunyai karakter kuat menahan erosi tanah, menertibkan bangunan liar di dalam kawasan dan membuat jalan atau pedestrian sebagai pembatas sepanjang RTH.

3. Rekomendasi yang disarankan berdasarkan penelitian ini dalam rangka pengembangan area rekreasi di kawasan RTH waduk Batujai, adalah sebagai berikut: 1) Pengembangan RTH sebagai taman kota ataupun hutan kota perlu pembatasan penggunaan areal taman untuk kegiatan/aktivitas yang berpotensi menimbulkan kerusakan lahan terutama vegetasi. Diperlukan juga pembatasan waktu kunjungan untuk mencegah pemanfaatan yang tidak diinginkan; 2) Fungsi dan manfaat RTH sangat tergantung kepada vegetasi (sebaran, komposisi/keanekaragaman jenis, dan tujuan penggunaannya), maka dalam ruang publik yang nyaman (Taman Kota ataupun Hutan Kota) perlu penataan vegetasi yang menunjukkan karakter area yang ingin dicapai berdasarkan jenis, bentuk, warna, tinggi, serta pola/jarak tanamnya; 3) Dari berbagai daya tarik yang berpotensi, festival budaya dan kesenian cukup banyak diminati. Atas dasar hal itu, hendaknya perlu upaya-upaya revitalisasi kesenian dan tradisi/budaya lokal sekaligus sebagai ajang pelestarian identitas lokal dengan diadakannya secara rutin event/pagelaran budaya dan seni yang diakomodir dengan memberikan sarana dan fasilitas pendukung; 4) Mempertimbangkan peningkatan jumlah penduduk dan kebutuhan RTH di masa mendatang, maka perlu adanya penetapan area-area budidaya yang belum terbangun seperti persawahan, tegalan, ataupun area yang tidak produktif untuk dapat dijadikan ruang terbuka hijau (taman dan hutan kota).

\section{REFERENSI}

Budihardjo, Eko dan Djoko Sujarto. 1999. Pembangunan Kota Berkelanjutan. Bandung: Penerbit ITB Carr S., M. Francis, L. Rivlin, \& A. Stone (1992). Public Space, Cambridge University Press, Cambridge.

De Chiara, J and Koppelman Lee. 1975. Urban Planning and Design Criteria, Second Edition. New York. Van Nostrand Reinhold Company

Fandeli, Chafid. 1995. Dasar-Dasar Manajemen Kepariwisataan Alam. Yogyakarta : Penerbit Liberty.

Fakuara, Y. 1987. Konsepsi Pembangunan Hutan Kota. Institut Pertanian Bogor. Bogor

Grey, Jane W. \& Frederick C. Deneke. 1996. Urban Forestry. John Wiley \& Sons Book Company, Inc., 
Gunn, C.A. 1998. Tourism Planning 2nd Edition. New York: Taylor and Francis

Hakim, R. 1991. Unsur perancangan dalam Arsitektur Lansekap. Jakarta: Bumi Aksara

Hong, W dan Guo, Renzhory. 2017. Indicator for quantitive evaluation of the social services fungction of urban greenbelt systems. A case study of Shenzou, China. Ecological Indicators. 259-267

Krier, Rob. 1979. Urban Space. Rizzoli International Publication: New York.

Lynch, Kevin. 1960, The Image of the City, The MIT Press, London-England.

Mill, R.C \& Morisson, A.M. 1985. Tourism System. Prentice Hall.

Porta, Sergio. 1999. The community and Public Space ecological thinking mobility and social interns the open space of the city of the future. Futures 31. 437-456

Rapuano, Michael et all. 1964. Open Space in Urban Design. Cleveland Ohio

Trancik, Roger. 1986. Finding Lost Spaces: Theories of Urban Design, John Wiiley and Sons: USA

Zlender, Vita. Thompson, W.C. 2017. Accessibility and West Peri-Urban green space for inner city dwellers. A competitive study landscape and urban planning. 193-205. Elsevier 